\title{
The Gaze at Work: Knowledge Relations and Class Spectatorship
}

\author{
Derek Nystrom
}

Recently, as I was finishing a book about class in 1970s U.S. cinema, I found myself thinking more and more about a particular moment in Saturday Night Fever (John Badham, 1977) that always leaves me unsettled. It occurs when Tony (John Travolta) helps Stephanie (Karen Lynn Gorney) move into a Manhattan apartment, where they happen upon its former owner Jay, a producer Stephanie knows from work and who is, we quickly discern, her ex-lover. At this point in the film, we already know that Stephanie, who hails from the same working-class Brooklyn neighborhood (Bay Ridge) as Tony, is a lower-middle-class striver who self-consciously and anxiously parades her newfound cultural knowledge and half-secured sense of class ascendancy. (Tony's attraction to and occasional animosity toward her stems in large part from her efforts to distance herself from the world he knows.) Jay's presence, however, immediately puts Stephanie in her place: he draws attention to her failed attempts at cosmopolitan sophistication by noting her incorrect speech (he reminds her that "no one says 'super' anymore") and incomplete mastery of cultural references (he chides her for buying the wrong book). Tony, meanwhile, shrinks into the background of the scene, only to confront Stephanie angrily outside about her relationship with Jay. The scene closes with Stephanie tearfully explaining that she needed Jay's help at her office because she felt out of her depths there - that she was tired of saying "I don't know" all the time.

Derek Nystrom is Associate Professor of English at McGill University, where he teaches film and cultural studies. He is the author of Hard Hats, Rednecks, and Macho Men: Class in 1970s American Cinema (New York: Oxford UP, 2009) and co-author, with Kent Puckett, of Against Bosses, Against Oligarchies: A Conversation with Richard Rorty (Charlottesville, VA: Prickly Pear Press, 1998; reprinted in 2002 as Prickly Paradigm \#3, University of Chicago Press). 


\section{IJCS}

The scene is unsettling not simply because of its troubling gender dynamics, as Stephanie is punished twice, first by the glib and condescending Jay, then by the hurt and confused Tony. It is also unsettling because the viewer has until this point been encouraged by the film to view Stephanie from something like Jay's perspective. We have been invited to take note that Stephanie mispronounces "vivacious" as "viv-ash-ous," that she mistakenly "corrects" Tony when he attributes Romeo and Juliet to Shakespeare, rather than Franco Zeffirelli, and so on. We have been asked, in other words, to take pleasure in how much more we know than Stephanie. And Saturday Night Fever's cinema of epistemic privilege does not only concern her: Tony, his friends, and his family are all objects of this gaze. When Tony chuckles approvingly about a male friend's sexual exploits right after he chastens Annette to decide whether she's "a nice girl or a cunt," we are meant to smirk at the irony of his blatant double standard, and to enjoy Tony's inability to recognize this same irony. When one of Tony's friends describes David Bowie's bisexuality to mean that he likes "men and boys," we are meant not only to understand how ignorance produces prejudice and vice versa, but also to feel a sense of superiority in this understanding. In short, the working-class denizens of Bay Ridge are offered up to the audience of Saturday Night Fever in such a way as to underline their limited perspectives and self-limiting worldviews, while we are encouraged to congratulate ourselves on our ability to see beyond their horizons. Indeed, the film's conclusion - in which Tony disgustedly rejects his community's racism (which had enabled him to win the dancing trophy unfairly at a local disco contest) and expresses a desire to move to Manhattan - is a happy one in large part because these actions are signs that his knowledge of his situation is approaching ours. Jay's appearance in Stephanie's apartment, then, provokes a kind of unpleasure, as we become aware of the smug undercurrent of our earlier enjoyment in our superior knowledge. In doing so, it also draws our attention to a particular kind of pleasure in knowing provided by dominant narrative cinema that I would like to explore in this essay.

Of course, there are many kinds of effects produced by differences between audience knowledge and character knowledge, as any student of cinematic narration can tell you - or, for that matter, anyone who has watched a horror film and yelled at the endangered heroine to look behind her. David Bordwell describes how narration in the fiction film can be more or less "restricted" to those of the film's characters, and more or less "communicative" in disclosing its narrative information. Bordwell's example from Hitchcock's Shadow of a Doubt (1943) illustrates both of these concepts: the film's narration in its opening moments is sometimes restricted to that of Uncle Charlie, yet in a key scene, the narration becomes decidedly less communicative, as Charlie reads an item in the newspaper and decides to conceal it from others in the home. This act of concealment extends to the audience, as we are denied access to the article that has provoked Charlie's actions - a narrational device which piques our curiosity and, in classic Hitchcock fashion, heightens our experience of tension. Other films are less restricted and/ or more communicative, creating situations in which we come to know more than a given character. Bordwell notes that many genres traffic in precisely this kind of epistemological gap, such as melodrama, in which "more omniscient narration 
tends to emphasize communicativeness so as to play up ironic and pathetic twists of which characters are unaware" (60).

That some of the most famous melodramas feature working-class protagonists (such as Stella Dallas (King Vidor, 1937)) leads me to the narrative organization I am thinking about, one that can in fact occur in any number of genres - a kind of epistemological gap between viewer and character that is dependent upon class relations. Of course, the idea that class and knowledge itself are interrelated is something of a pop sociological truism. In fact, many mainstream accounts of class identity (not incorrectly) list education level as one of its key determining elements. ${ }^{1}$ Thus, it would seem unsurprising that one characterological shorthand for working-class identity in dominant cinema would be a perceptible lack of education and/or mental skill. One of the dangers of this characterization of knowledge and class, though, is that it tends to naturalize this connection-it suggests that those who inhabit the working class are there because of their lack of knowledge, while those in the middle and upper classes are inherently more intelligent. It is an understanding of knowledge and class that sees the former as an inert fact of nature, and the resulting class structure as a simple product of meritocracy. As I hope to show below, the relationship between knowledge and class is better understood as a product of material struggles; class hierarchies determine who has access to and control over knowledge, while claims to knowledge (and claims to the legitimacy of one's knowledge) structure class position. To put it more concisely, knowledge is a key terrain upon which class struggles are fought. In what follows, I will show how a certain kind of pleasure that dominant narrative cinema often offers us - one derived from a particular organization of what we might call its knowledge relations - is implicated in these class struggles over and about knowledge.

\section{The Knowledge Relations of Taylorism}

To show how class and knowledge have been mutually constitutive of each other in the $20^{\text {th }}$ century, let me offer a brief overview of Taylorism, the form of industrial organization that emerged at the beginning of that century (the same precipitous moment, of course, that also saw the birth of cinema). Taylorism is named after Frederick Taylor, whose theory of "scientific management" promised to apply scientific principles to the organization of the capitalist production process. Briefly, Taylorism can be described as the effort to separate the conception, design, and management of the production process from the actual execution of the labor itself. In other words, it is a regime in which managers function as the brain, while workers function as the hand. Harry Braverman's classic account in Labor and Monopoly Capital describes how Taylorism's rise served to reinforce the class hierarchies of capitalism through its aggressive restructuring of knowledge relations at the site of production. Braverman notes that, before Taylorism, one of the strongest points of resistance to capital's control of the labor process had been the workers' greater knowledge of this process - a knowledge that could thus be utilized to challenge capital's prerogatives. To capital, then, the "generalized distribution of knowledge of the productive process among all its participants" was "not merely "unnecessary,' but a positive barrier to the functioning of the capitalist mode of production" 
(82). The attraction of Taylor's scientific management, therefore, was not simply its promise to make the workplace more efficient by minimizing what it saw as "superfluous" and "wasteful" shop floor activity, but also its efforts to appropriate knowledge of the labor process and place it under capital's control. Taylor argued that managers must collect "all of the traditional knowledge which in the past has been possessed by the workmen" and then go about "classifying, tabulating, and reducing this knowledge to rules, laws, and formulae" (qtd. in Braverman 112). In doing so, Taylor continued, "all possible brain work should be removed from the shop and centered in the planning or laying-out department" (qtd. in Braverman 113). This separation of conception from execution also entailed the reduction of each worker's labor to a standardized and routinized task, which further attenuated the workers' agency and control within the production process. The end result was a workplace regime that, in Braverman's words, "strip[ped] the workers of craft knowledge and autonomous control and confront[ed] them with a fully thought-out labor process in which they function as cogs and levers" (136).

In the Taylorized workplace of the $20^{\text {th }}$ century, then, the workers are placed in a degraded epistemological position; their knowledge is limited to the simplified and atomized tasks they are assigned, as they are actively denied any understanding of the larger production process. The managers, by contrast, are in a privileged epistemological location, in that their synoptic perspective on the production process enables them to know "better than the workers themselves" the workers" "own life activity," as Braverman puts it (116). What this history shows us is that class domination is secured in part through the forcible instantiation of an epistemological hierarchy, whether that hierarchy is imposed on industrial labor (Taylor's immediate concern) or the "immaterial" but still closely managed labor of figures like Fever's Stephanie, who feels anxious at her secretarial job precisely because she does not know enough about how things work at her office.

This same epistemological hierarchy frequently informs the structure of dominant film narrative, especially when it depicts the working class. In these kinds of films, we often have information made available to us (via less restricted and more omniscient narration) about larger story arcs and their social contexts that working-class characters do not possess. In many cases, more communicative narration organizes dialogue, story, and even mise-en-scène so as to emphasize for the viewer linguistic, visual, and dramatic ironies that elude working-class characters. In these ways, figures like Stephanie and Tony in Fever are often depicted as possessing knowledge of themselves and of their situation — we might even say their "own life activity" - that is demonstrated quite pointedly to be limited, partial, blinkered. We are able to recognize their epistemological perspective as limited, in turn, because these modes of narration often offer us a more complete, synoptic overview of their world. In this way, this narrative structure has the effect of placing the spectator in a position akin to that of a manager. (Recall that Jay, whose view of Stephanie we share, albeit uneasily, is her superior at work.) If Laura Mulvey famously declared that a patriarchal society generates a dominant cinema that asks its viewers to take on a male gaze, a consideration of the $20^{\text {th }}$ century's Taylorized workplaces suggests that we should ask whether our dominant cinema often 
posits a managerial gaze as well. After all, in a world ordered by class imbalance, perhaps a certain pleasure in knowing has been split between an actively knowing professional-managerial class and a passively known working class.

\section{Class and Film Theory}

Of course, to invoke the "gaze" is to raise the questions of spectatorial positioning and the construction of the "textual spectator," a mode of investigation that has been challenged from a number of different critical perspectives. Some of the most common objections to the very idea of theorizing spectatorial positioning are: (a) the resulting models are often ahistorical and insufficiently attuned to differences between individual texts; (b) they overestimate the power of a text to impose a particular mode of reception on its spectator, and underestimate the ways in which texts can offer multiple points of engagement, interest, and identification; and (c) they overgeneralize spectatorial responses without grasping the crucial role of the various social contexts of reception. With respect to (a), I suggest below that an attention to knowledge relations enables us to register and analyze both historical change and textual specificity. Furthermore, while I agree with much of (b) and (c), it is also surely the case that texts exert some influence on the interpretative practices and affective responses of their spectators (even if this influence is inflected in multiple ways), and that we cannot understand such influences by only examining the contexts in which these texts are viewed; we must also interrogate the textual material at hand in order to approach a complete understanding of the class dynamics of the cinematic experience. This last task is of particular importance, since film studies has not yet developed a robust critical vocabulary for describing how class is signified textually. When class is discussed within film studies, it is most often addressed as an extra-textual feature that shapes the various contexts of a film's reception, rarely as a force operating within the film itself. As a result, the relationship of this crucial feature of social life to cinematic signification has been significantly undertheorized.

By addressing the class dimensions of the textual spectator, I aim to activate a set of questions about spectatorial positioning that have been dormant in film studies since what we might call the theory explosion of the 1970s. This explosion is most often associated with work published in Screen, which derived much of its critical framework from the vocabularies of structuralism and especially psychoanalysis. However, despite the tremendous productivity of these psychoanalytic perspectives to film theory in grasping the ways in which a spectator's position is shaped by gender as well as sexual and racial dynamics, psychoanalysis has had little to say about specifically class-related structures of film spectatorship. However, a suggestive but now largely forgotten debate that arose around the questions of psychoanalysis, class, and spectatorial positioning during the late 1970s - one which took place between critics affiliated with Screen and those at the Birmingham Centre for Contemporary Cultural Studies_- points to the significant critical potential for an inquiry into Taylorism's knowledge relations and those of cinematic narration.

One of the most direct confrontations between the critical perspectives of the Birmingham Centre and Screen was the exchange occasioned by Rosalind Coward's 
1977 essay in Screen, 'Class, 'Culture,' and the Social Formation.” The central issue of this debate was the relationship between psychoanalysis and Marxism - the latter critical perspective being the dominant orientation in British cultural studies. In her essay, Coward acknowledges that the psychoanalytic work published in Screen up to that point had little to say with respect to class, but she nevertheless asserts that "the sort of theories of representation that Screen has drawn on also have consequences at the level of class analysis, and indeed at the level of conceptualization of the social formation" (76). The theories to which Coward refers are those derived from Lacan's work, which she describes as "a materialist analysis of signifying processes, of discursive practices involving subject positions, and also of the individual as subject" (105). For Coward, the Lacanian accounts of subject formation - and their elaboration in the more Marxist-oriented work of Louis Althusser, Barry Hindess, and Paul Hirst — challenge the theoretical presuppositions of the Birmingham Centre's work, in which, she claims, "the ideological and political are finally reduced to being an expression of a class interest or position" (76). She contends, "It is never a question of what class produces what form or what content of a signifying practice, but rather how systems of representation inscribe (ideological) positions" (95). In other words, the critic should not inquire after a film's class origin or "meaning"asking, for example, if a film embodies good working-class, socialistic values, or if it betrays a bourgeois false consciousness. Instead, what is to be examined is the relation into which the film places its viewer, and how it thus creates a subject position for this viewer. Coward argues that Marxism does not offer the theoretical tools for such an examination, because "Marxism has never properly accounted for the individual construction" (104). ${ }^{2}$ Therefore, Coward argues, film theory must use the critical vocabulary of psychoanalysis, especially its Lacanian incarnations, since it is concerned with precisely the subject's construction in discourse. This vocabulary, of course, became the central one for film theory's project of examining the spectator that is constructed by the cinematic text.

The response authored by several members of the Birmingham Centre, published in a later issue of Screen, acknowledges what they call "the inadequate theorisation, within marxism, of the position of "the subject"" (Chambers et al 118). They qualify this acknowledgement, though, by insisting that "it is not self-evident that marxism stands and falls depending on whether or not it contains a theory of the 'speaking subject" (119); indeed, elsewhere the Birmingham Centre writers argue that the subject must be conceived "not exclusively [...] [as] the 'speaking subject' but also the producing and consuming subject" (Chambers et al 118, emphasis added). However, despite their profound disagreement with both Coward's characterization of their work and what they see as the ahistorical nature of Lacanian thought, the Birmingham theorists also argue that critical inquiry into subject formation could usefully supplement the Marxist project. Such an undertaking would involve, they write, an account of

how the subject is constituted as a contradictory result (perhaps along the lines of Marx's demonstration as to how the moment of exchange is constitutive of the 'economic subject' as an 
effect) - thus, the interpellation of the 'subject' in historicallyspecific positions (class positions, political-juridical positions, ideological positions) (Chambers et al 119).

To a large extent, though, this suggested program for understanding the interpellation of spectators as class subjects has not been explored by film studies. To be sure, a good deal of film theory has sought to illustrate how realist cinema imposes bourgeois ideology on its viewers. Jean-Louis Baudry and Christian Metz both famously argued that the cinematic apparatus itself, especially as it is mobilized by realist cinema, places the viewer in the position of the "transcendental subject," offering an imaginary coherence that corresponds to the bourgeois ego. Colin MacCabe similarly posited that cinematic realism functions in much the same way that third-person narration operates in the realist novel —it offers a seemingly transparent, unaligned, and objective "metalanguage" that speaks for the "real," and against which the limited and partial discourses of the various characters are to be compared and evaluated, thus creating "a position of pseudo-dominance" and mastery for its spectators (24). However, the problem with these sorts of claims, as Antony Easthope has observed, is that they discuss "modes of representation [...] on an epochal scale," and thus do not offer critical tools that could attend to more historically specific shifts in the class dynamics of film narrative (127). As a result, these earlier arguments about spectatorial positioning and bourgeois subjectivity tend to produce the same interpretation for virtually all realist cinema: that every realist film always generates a metalanguage that instantiates a position of transcendental subjectivity for its spectator. Such approaches do not simply downplay the complexity of a given cinematic text; they also present an account of class power that is static and univocal, one in which bourgeois ideology always succeeds at containing any alternative way of seeing and knowing the world.

\section{The Dialectics of Knowledge Relations}

In contrast to these approaches, a consideration of the connections between Taylorism's epistemic hierarchies and those of cinematic narration allows us to register a particular period's and an individual text's specificity, because it enables us to analyze the ways in which various perspectives and knowledges are constituted in relation to each other by a given film. To refer again to Fever: in the scene immediately following the one discussed at the beginning of this article, Tony consoles Stephanie by describing the various features of the Brooklyn Bridge, in what amounts to a fairly obvious metaphor for his knowledge of the difficulty of crossing class lines - of making the trip from Brooklyn to Manhattan. This is a knowledge that we can assume Jay the record producer does not value, yet it is a knowledge that the film privileges over Jay's smug display of sophistication. Therefore, while we can describe the film's central narrative strategy as offering a managerial gaze, we can also see how the film aligns us at various moments with its working-class characters and their knowledges of their social context. In these moments, the working-class knowledges do not cease to be partial or limited - after all, Tony knows a lot about the Brooklyn Bridge, but nothing about the borough that lies on the other side of it-but the value of this 
knowledge is at least momentarily confirmed and endorsed.

I would argue that such a diversity of classed spectatorial perspectives (even within a particular film) is possible because the epistemological relations of class are themselves always under negotiation, and always constituted dialectically. For example, as John Frow has argued, the rise of Taylorism marked a transformation of "social understandings of what counts as knowledge," so that the artisanal knowledge of workers was redefined as a "skill," which was then devalued in comparison to - or made irrelevant by - the rationalized and scientific "knowledge" of the professional-managerial class (119). In other words, it is not as if the workers' knowledge completely disappeared; it was just placed in a new laboring context, and a new dialectical relation with professional-managerial knowledge, that privileged the latter mode. However, such a distinction is not won once and for all, but is continually reworked and remade as it is challenged - especially by the ongoing development of working-class knowledges of the labor process that, while they may be deprived of a synoptic managerial perspective, nonetheless compete with and challenge the latter's authority.

By attending to these dynamics, we may grasp how different films can stage various classed knowledges, putting them into dialogue and pitting them against each other as they compete for narrative and affective authority. Such an approach thus allows us to grasp textual and historical variation. A Marx Brothers film-which aligns the viewer with its insurgent, insouciant parody of "official" knowledge, delivered in urban, ethnic accents - will map its knowledge relations differently than, say, The Philadelphia Story (George Cukor, 1941), which eventually (and systematically) indicts the limited perspectives of the non-patrician characters with whom the viewer had initially been aligned. Similarly, the cinema of a tumultuous period in class relations, such as that of the 1930s, will reveal a differently calibrated set of epistemic hierarchies than those of a period in which capital's reign is much more secure, such as the 1980s. And while it is this article's perhaps polemical contention that what I am calling the managerial gaze is the governing, hegemonic epistemological perspective of dominant narrative cinema, this method of inquiry will also allow us to see how this hegemony is, as Antonio Gramsci described it, a "moving equilibrium" (qtd. in John Clarke et al 40) —one that is always in the process of being re-made, as its dominance is always in the process of being rewon. By examining the interplay of these differently classed knowledges in various cinematic texts and periods, we can limn the epistemological structures of class domination while also registering the oppositions and resistances to this domination.

\section{Middle-Class Knowledge and the Paranoid Conspiracy Film}

The theory of class spectatorship I am proposing here also enables us to inquire into other class antagonisms. Many theorists, such as Barbara and John Ehrenreich, Erik Olin Wright, and Nicholas Abercrombie and John Urry, have noted how the development of the modern middle class (or, more precisely, the professionalmanagerial class) derived from capital's need for specialists to engineer and manage the Taylorized workplace, and for professionals whose task is to guarantee the reproduction of capitalist production relations by ensuring the education, health, 
and welfare of the workforce. Thus, while the Taylorist organization of production serves the interests of capital, the most immediate material antagonism it generates is the one between worker and manager - the antagonism with which this essay has been concerned thus far. However, the authority of professional and managerial knowledge rests on the class's claims to occupational autonomy: the freedom to determine, according to their specialized knowledge, the organization of their work tasks as well as their standards for efficiency and excellence. This need for occupational autonomy often puts the middle class in conflict with capital, whose interests they otherwise serve: we can think here about the resistance of doctors to the control of health care by insurance companies, or our own profession's defense of tenure and other forms of academic freedom against increasingly corporatized universities. These are signs of the ways in which the dominance of professional and managerial knowledges - and the powers that are granted to those knowledges - are never guaranteed in advance, but are also the product of class struggle.

These knowledge-oriented class dynamics might help explain those moments in which professional-managerial class knowledge is depicted cinematically as also limited and partial. I am thinking here of the style of film known as the paranoid conspiracy thriller, which usually features a middle-class protagonist who utilizes his or her professional knowledge to uncover a conspiracy whose contours he or she is only dimly aware of - a limited awareness that we as spectators most often share. Rather than positing the alleged mastery and control of the bourgeois ego, these films suggest ways in which the professional-managerial class itself often has only partial knowledge of the designs of large, powerful, mysterious entities - which, following Fredric Jameson, we might read as figures for multinational capital — that shape and determine the conditions under which we live.

For example, Alan Pakula's All the President's Men (1976), which is about Woodward and Bernstein's efforts to uncover the Watergate conspiracy, foregrounds the professional tasks of knowledge-gathering and -interpretation and their capacity to function as tools of resistance against the ruling class (signified here by the Nixon presidency). However, much of the film's drama derives not from the grand discoveries of the journalists' investigative work - in fact, the film's action ends before a number of the key revelations of the Watergate scandal actually occur-but rather from the painstaking process of locating, documenting, and authenticating information. Indeed, All the President's Men spends most of its running time on fairly minor details of the investigation, and even follows the reporters down a few blind alleys and dead ends. As a result, even though we know how the story is going to end-our knowledge of history means that we know more than the protagonists - the film, as one reviewer put it at the time of its release, "boxes the audience into the same closed perspective, forcing them, along with the reporters, to batten excitedly on each new clue" (Combs 189). The spectator, then, has a kind of double perspective on the film's events: we often don't know the solutions to the individual mysteries that the reporters are trying to solve-our knowledge is limited to theirs - but we know about the big mystery, the Watergate conspiracy, whose contours they are just beginning to discern over the course of the film.

One key sequence from the film visually dramatizes this double perspective. After 


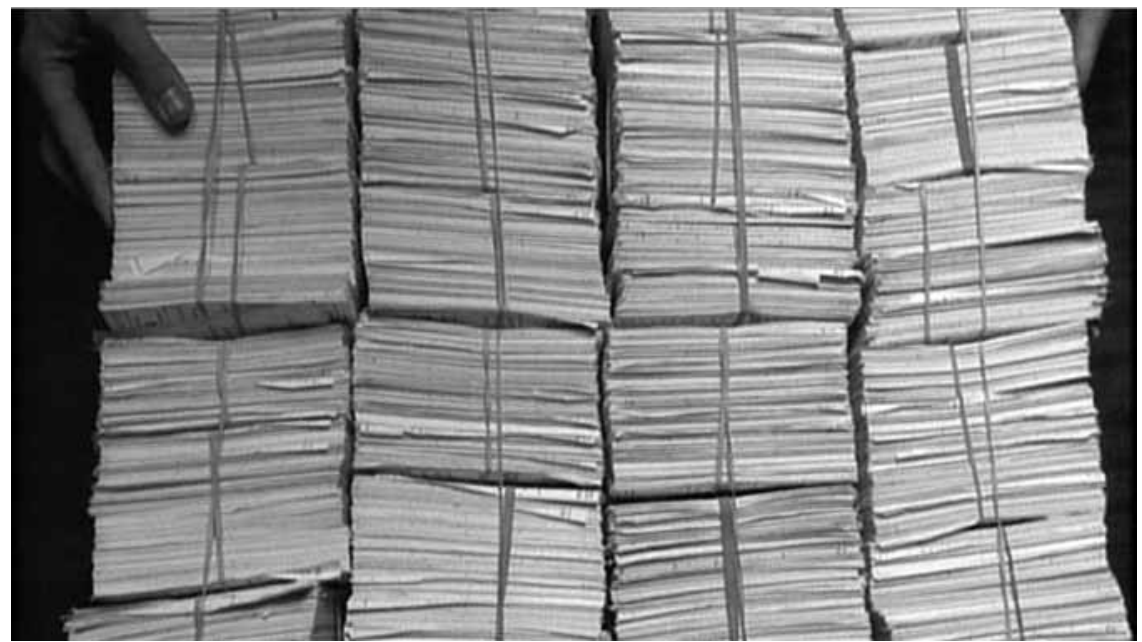

Fig. 1 - From All the President's Men (Warner Bros., 1976)

Bernstein is told by a source that Howard Hunt, one of the Watergate conspirators, has been investigating Senator Ted Kennedy, he and Woodward attempt to track down Hunt's library records at the Library of Congress. The sequence ends with a famous series of crane shots, as we ascend from a close-up on the stacks of library slips the reporters are examining to an extreme overhead perspective that causes Woodward and Bernstein almost to disappear in the massive architecture of the Reading Room (see fig. 1 and 2). As many critics have noted, these overlapping shots serve as a kind of visual analogue for the reporters' position with respect to the Watergate conspiracy - burrowing through piles of information, hoping to locate clues that will indicate the larger web of conspiracy whose shape currently exceeds their understanding, and which seems to dwarf their prosaic and painstaking efforts. What is striking about these shots is that they also operate as an enactment of our double perspective as spectators: we don't know if Howard Hunt's name is going to appear on one of those slips of paper that fill the screen at the beginning of the shot - we share the protagonists' limited knowledge — but we know Hunt's place, figuratively speaking, in the larger patterns of conspiratorial organization visualized by the concentric rings of the Reading Room. Furthermore, if, as Jameson suggests, what is offered here is an "impossible vision of totality" (79) - that the symmetries of the Reading Room serve not merely as a visual metaphor for the film's actual conspiracy, but also as an allegory for the larger structures of late capitalism - then we might regard All the President's Men as a representation of the place of professional-managerial knowledge within this totality. Such a reading would also reinforce Andrew Hoberek's provocative suggestion that Jameson's model of "cognitive mapping" itself speaks quite specifically to the middle-class laborer's position in multinational capitalism, rather than that of postmodern subjects generally (119-27). In this way, the film serves as a kind of wish fulfillment, a narrative that traces the possibility that professional knowledge, successfully deployed, may be used to counter the power of capital. For the purposes of this 


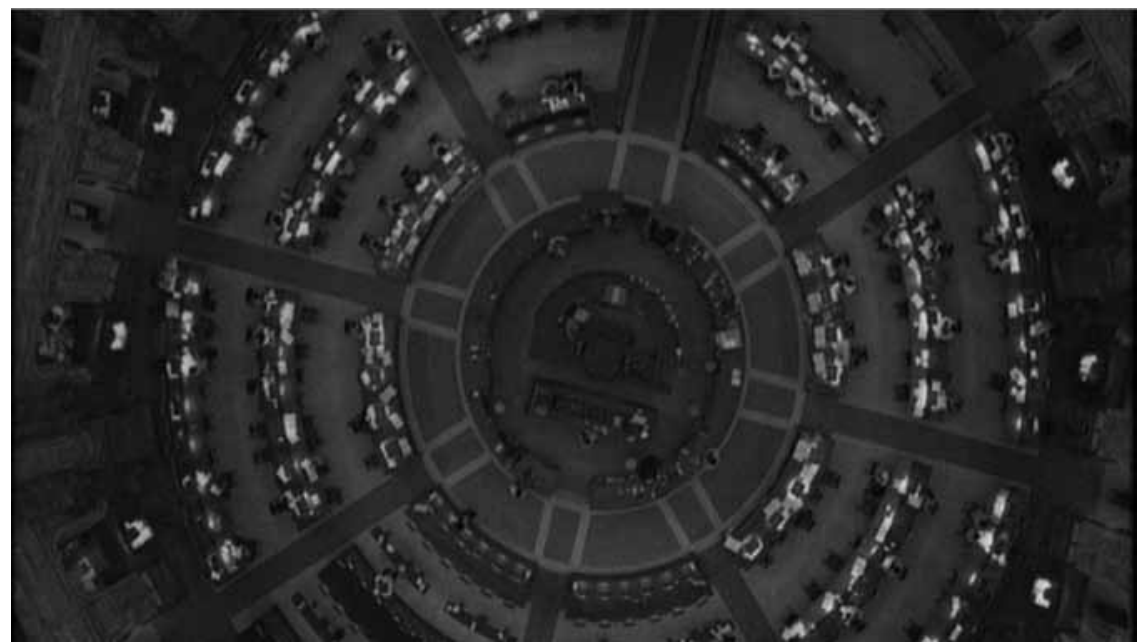

Fig. 2 - From All the President's Men (Warner Bros., 1976)

article, what is most noteworthy is how the film's implied spectatorial position underlines the difficulty of this task. All the President's Men occasionally holds out the admittedly cold comfort of grasping the social totality, even as it places us epistemologically in the position of the Men Who Do Not Know Enough, and who struggle to use their professional skills and expertise to resist the machinations of those who direct this totality.

\section{Knowledge Relations After Taylorism}

It can been argued that the forms and conditions of work depicted in All the President's $M e n$ - the immaterial labor of information processing by semi-autonomous, quasiself-directed employees - are more typical of contemporary production regimes than those of the Taylorist factory. Many theorists have described how, during the second half of the $20^{\text {th }}$ century, advanced economies shifted toward a form of production variously termed "post-industrial," "post-Fordist," or "informationalized"- - a shift that challenged Taylorist forms of workplace organization and, according to Michael Hardt and Antonio Negri, in turn contributed to the economic and political crises of the late 1960s and 1970s. (One could make the case that the proliferation of U.S. films about the working class in the 1970s, as well as the efflorescence of Marxist critical thought in that same decade, are symptoms of this shift and its attendant crises.) Specifically, Hardt and Negri posit that in this new stage of capitalist production, the Taylorist "assembly line has been replaced by the network as the organizational model of production" (295). On their account, the contemporary workplace is no longer characterized by a vertical model of epistemological domination and control, in which the manager-engineer enjoys a monopoly on knowledge of the working process, utilizing this superior epistemic position to direct and discipline the activity of workers whose own knowledge is partial and limited. Instead, the new structures of work engendered by the rise of information technologies do not simply enable but in fact require the development of horizontal networks of knowledge about the 
laboring process between workers. In this way, the epistemological hierarchies of the Taylorized workplace are destabilized by this new organization of labor.

While it would take me too far afield to address fully the validity of these claims, I will simply note here that I agree with critics who have argued that such accounts tend to mistake the potential of such new structures of work for their actual implementation, which too often reveal the persistence of epistemological hierarchies inherited from Taylorism. ${ }^{3}$ The rise of information technologies has enabled some workers to establish horizontal networks of communication and organization, but it has also generated a vast array of surveillance mechanisms that management has utilized to monitor them - in other words, to gather knowledge about their workers in order to discipline and control them. Citing a 2001 survey in which $77.7 \%$ of companies "acknowledged routine electronic monitoring of their employees' activities," Andrew Ross comments that "supervision of workers' time and actions [is] even more systematic in the computerized workplace than it had been under the factory foreman" (12). Without denying the liberatory possibilities theorists like Hardt and Negri identify in information technology and the new labor processes it makes possible, I agree with Manuel Castells that

technology per se is not the cause of the work arrangements to be found in the workplace. Management decisions, systems of industrial relations, cultural and institutional environments, and government policies are [...] fundamental sources of labor practices and production organization." (256)

Therefore, even as the "Taylorist assembly line [...] becomes an historic relic" in many advanced economies (but not for the "millions of workers in the industrializing world," Castells quickly adds [258]), it would be too hasty to suggest that the epistemological hierarchies it instantiated have been smashed (258).

In the end, though, the debates about the potential of informationalized production to alter the balance of class power in the workplace indicate how crucial the terrain of knowledge has become in the constitution of class position. If anything, the "knowledge economy" heightens the stakes of battles over different class knowledges - their constitution, organization, dissemination, and legitimation. The networked laborer's efforts to gain some form of control over his or her working conditions - usually by utilizing the same computer that registers and records his or her every webpage visit - can be seen as a continuation of the struggles for epistemic mastery of the labor process inaugurated by Taylorism's severance of conception and execution.

Film theorists have long observed that psychoanalysis and cinema were born at roughly the same time, and that this contemporaneous birth at the end of the $19^{\text {th }}$ century helps underwrite the use of the former critical vocabulary to analyze the latter cultural form. This essay has inquired into the kinds of critical practices that might be induced by the recognition that Taylorism also came into being at this same moment. Cinema dawned during a time that saw not only a new understanding of the psyche, but also a new arrangement of labor, which entailed a new organization of knowledge. But while psychoanalysis's accounts of the significance of our dreams have so powerfully and productively shaped our critical considerations of the dream- 
like images and narratives projected in the darkened theatre, film studies has yet to explore fully how Taylorism's transformation of knowledge relations might relate to those of the cinema. We must ask what it would mean to examine the products of this "dream factory" and consider their relationship not to dreams, but to the factory.

\section{Notes}

I would like to thank Jenny Burman, Erin Hurley, Carrie Rentschler, and Ned Schantz as well as the anonymous reviewer at the Iowa Journal of Cultural Studies for their thoughtful suggestions to this article.

1 The 2005 New York Times series on "Class Matters," for example, determined class position by a mix of income, education, wealth, and occupation. See Class Matters (New York: Times Books, 2005).

${ }^{2}$ Coward argues that the Birmingham School's belief in the fundamental determination of the economic sphere means that they ultimately treat cultural representations as mere expressions of class worldviews - worldviews which are constituted in a non-contradictory, unified manner in the ontologically prior sphere of the economic; furthermore, she accuses them of characterizing dominant cultural representations as forms of false consciousness deployed in an instrumental fashion by the ruling classes. To my mind, Coward's critique grossly mischaracterizes the Birmingham Centre's emphatically non-reductionist account of the relationship between economic class and ideological production, and meanwhile presents an alternative model of the social formation that begs as many questions as it answers.

${ }^{3}$ See, for example, Dyer-Witheford, "Empire, Immaterial Labor, the New Combinations, and the Global Worker."

\section{Works Cited}

Abercrombie, Nicholas and John Urry. Capital, Labour and the Middle Classes. London: Allen and Unwin, 1983.

All the President's Men. Dir. Alan J. Pakula. DVD. Warner Bros., 1976.

Baudry, Jean-Louis. "Ideological Effects of the Basic Cinematographic Apparatus." Trans. Alan Williams. Movies and Methods, Vol. II. Ed. Bill Nichols. Berkeley, CA: University of California Press, 1985. 531-542.

Bordwell, David. Narration in the Fiction Film. Madison, WI: University of Wisconsin Press, 1985.

Braverman, Harry. Labor and Monopoly Capital: The Degradation of Work in the Twentieth Century. New York: Monthly Review, 1974.

Castells, Manuel. The Rise of the Network Society. $2^{\text {nd }}$ ed. Oxford, UK: Blackwell, 2000. Chambers, Iain et al. "Marxism and Culture." Screen 18.4 (1977/78): 109-119.

Clarke, John et al. "Subcultures, Cultures and Class: A Theoretical Overview." Resistance Through Rituals: Youth Subcultures in Post-War Britain. Eds. Stuart Hall and Tony Jefferson. London: Hutchinson, 1976. 9-74.

Combs, Richard. Rev. of All the President's Men, dir. Alan J. Pakula. Sight \& Sound 45.3 (1976): 189-90.

Coward, Rosalind. "Class, 'Culture,' and the Social Formation." Screen 18.1 
(1977): 75-105.

Dyer-Witheford, Nick. "Empire, Immaterial Labor, the New Combinations, and the Global Worker." Rethinking Marxism 13.3/4 (2001): 70-80.

Easthope, Antony. "The Trajectory of Screen, 1971-79." The Politics of Theory: Proceedings of the Essex Conference on the Sociology of Literature, July 1982. Eds. Francis Barker et al. Colchester, UK: University of Essex Press, 1983. 121-133.

Ehrenreich, Barbara and John. "The Professional-Managerial Class." Between Labor and Capital. Ed. Pat Walker. Boston: South End, 1979. 5-45.

Frow, John. Cultural Studies and Cultural Value. New York: Oxford UP, 1995. Hardt, Michael and Antonio Negri, Empire. Cambridge, MA: Harvard UP, 2000. Hoberek, Andrew. The Twilight of the Middle Class: Post-World War II American Fiction and White-Collar Work. Princeton, NJ: Princeton UP, 2005.

Jameson, Fredric. The Geopolitical Aesthetic: Cinema and Space in the World System. Bloomington, IN: Indiana UP, 1992.

---. Postmodernism, or, The Cultural Logic of Late Capitalism. Durham, NC: Duke UP, 1991.

MacCabe, Colin. "Realism and the Cinema: Notes on Some Brechtian Theses." Screen 15.2 (1974): 7-27.

Metz, Christian. “The Imaginary Signifier.” Narrative, Apparatus, Ideology. Ed. Philip Rosen. New York: Columbia UP, 1986. 244-278.

Correspondents of The New York Times. Class Matters. New York: Times Books, 2005. Nystrom, Derek. Hard Hats, Rednecks, and Macho Men: Class in 1970s American Cinema. New York: Oxford UP, 2009.

Ross, Andrew. No-Collar: The Humane Workplace and Its Hidden Costs. New York: Basic, 2003.

Saturday Night Fever. Dir. John Badham. DVD. Paramount, 1977.

Wright, Erik Olin. Classes. London: Verso, 1985.

---. "A General Framework for the Analysis of Class Structure." The Debate on Classes. Ed. Erik Olin Wright et al. New York: Verso, 1989. 3-43. 